\title{
Strategies for the Extraction, Purification and Amplification of Metagenomic DNA from Soil Growing Sugarcane
}

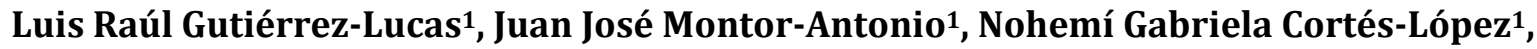 \\ Sandra del Moral ${ }^{*}$ \\ ${ }^{1}$ División de Estudios de Posgrado, Universidad del Papaloapan, Tuxtepec, México \\ ${ }^{2}$ Instituto de Biotecnología. Universidad del Papaloapan,Tuxtepec, Oaxaca, México \\ Email: smoral@unpa.edu.mx
}

Received 21 April 2014; revised 31 May 2014; accepted 19 June 2014

Copyright (C) 2014 by authors and Scientific Research Publishing Inc.

This work is licensed under the Creative Commons Attribution International License (CC BY). http://creativecommons.org/licenses/by/4.0/

(c) (i) Open Access

\section{Abstract}

Recently, studies were initiated to investigate the metagenome, which represents the genomes of cultured and uncultured microbes, as a rich source for isolation of many novel genes. The metagenomic approach originated from the molecular analysis of microbial communities, which revealed that the majority of microorganisms in nature were not cultivable by standard culturing techniques. Therefore, most microorganisms in nature have not been characterized. Although numerous methods have been reported for direct DNA isolation and purification from microorganisms in soil, the sample preparation procedures and experimental conditions used in different studies vary widely. Soils are therefore one of the most challenging environmental matrices from which to obtain microbial DNA that will support PCR. The Papaloapan River is the second largest river basin in México. For the climatic conditions of this region, there is great diversity in plants, animals and microorganisms. In the Papaloapan region different fruits are grown, however, the main crops are sugarcane and pineapple. In this work the extraction of DNA from soils of sugarcane cultivation was performed. We used PCR tests to assess the quality of DNA extracted from soil by amplifying the $16 \mathrm{~S}$ rDNA gene. Changes in both protocols were performed; satisfactory results were obtained as to the quality of DNA and gene amplification. These results will allow continuing the metagenomic studies, such as sequencing, library construction and identification of enzymes cellulase and amylase activity. It is the first time these studies were performed in the Papaloapan region.

\section{Keywords}

Metagenomic, Soil DNA, Metagenome, Papaloapan Basin

\footnotetext{
${ }^{*}$ Corresponding author.
}

How to cite this paper: Gutiérrez-Lucas, L.R., Montor-Antonio, J.J., Cortés-López, N.G. and del Moral, S. (2014) Strategies for the Extraction, Purification and Amplification of Metagenomic DNA from Soil Growing Sugarcane. Advances in Biological Chemistry, 4, 281-289. http://dx.doi.org/10.4236/abc.2014.44034 


\section{Introduction}

Papaloapan Basin is the common name to refer to the Papaloapan River watershed and its tributaries. It is located in the southeast of Mexico encompassing 3 states (north of Oaxaca, south of Puebla and Veracruz center). It has fertile land and a warm and humid climate. These factors have made it a mega-diverse area, which has led to the development of agriculture, livestock, fisheries and the sugar industry. One of the most representative crops of the region is sugarcane, which occupies $30 \%$ of the arable surface [1] [2].

Soil is considered as a complex environment, which appears to be a major reservoir of microbial genetic diversity. The complexity of microbial diversity results from multiple interacting parameters, which include $\mathrm{pH}$, water content, soil structure, climatic variations and biotic activity [3]. The total number of microbial cells on Earth is estimated to be $10^{30}$. Prokaryotes represent the largest proportion of individual organisms, comprising $10^{6}$ to $10^{8}$ separate genospecies [4]. However, the majority of soil bacteria and fungi cannot be cultured via traditional laboratory techniques and must be identified using molecular methods [5]. Diversities in bacterial communities are normally determined by phenotypic characterization of isolated strains. A problem is that phenotypic methods can be used only on bacteria which can be isolated and cultured [6]. In the past decade, applications of molecular biological approaches have provided unique insights into the uncultured microbial communities of soils and waters because they avoid biases inherent in traditional culture-based microbiological methods [7]. Current estimates indicate that more than $99 \%$ of the microorganisms present in many natural environments are not readily culturable and therefore not accessible for biotechnology or basic research, which leads to a limited knowledge of their metabolic capabilities [8]-[10]. Molecular methods are increasingly being used to explore the microbial diversity of environmental systems without needing to isolate microorganisms from their natural environment, especially because many relevant organisms have proven difficult to isolate from their environmental sources [11]. Recently, there has been an increase in the number of studies using a metagenomic approach to investigate the diversity, metabolic pathways and catalytic potential of uncultured microorganisms. The term metagenome was introduced to describe the genomes of complex microbial communities found in natural habitats, only a small fraction of which can be cultured [12] [13]. The field of metagenomics offers unique perspectives on culturable and non-culturable microorganisms and their biosynthetic products [14]. The metagenomics has been applied to study a range of soil environments, and comparisons with cultivation techniques should include biases in the methods used to extract DNA from soil. Different DNA extraction methods are widely used, although they each have biases that restrict the diversity of the so-called metagenomic DNA [15]. Metagenomic is based on direct isolation of nucleic acids from environmental samples have proven to be powerful tools for comparing and for exploring the ecology and metabolic profiling of complex environmental microbial communities, as well as for identifying novel biomolecules by use of libraries constructed from isolated nucleic acids [4]. Investigation of metagenomes became possible after the development of strategies for the isolation of environmental DNA [12]. DNA can be isolated from bacterial fractions containing 50 to $80 \%$ of the soil bacteria and may provide genetic information about the nonculturable bacteria in soil [6] [16]. However, successful application of molecular techniques relies on effective recovery of nucleic acids from environmental samples. A variety of methods have been developed and used to directly recover nucleic acids from environmental samples [17]. Successful characterization of microbial communities is therefore often dependent on DNA that is extracted from the environment. The extraction of high-quality DNA from soil can be problematic [5], for efficient analysis proper purification is necessary. In order to perform the first metagenomic studies on soils of sugarcane cultivation in the region of Papaloapan and expand knowledge about diversity and catalytic potential of microorganisms in the soil, in this work, DNA was extracted from the soil. PCR assays were performed to amplify a region of the $16 \mathrm{~S}$ rDNA gene. The extraction and PCR protocols were modified in steps that were considered critical by our research group.

\section{Material and Methods}

\subsection{Soil Samples}

Samples were collected from four sites. The four sites belong to the same plot (lat. $18.00^{\circ} \mathrm{N}, 96.07^{\circ} \mathrm{W}$ and alt. 32 m.a.s.1.) and samples were collected in April 2013. This soil is used to grow sugar cane and is classified as rhizosphere and composed of clay: $51.96 \%$, silt: $30 \%$, sand: $18.04 \%$ and $\mathrm{pH}$ : moderately acid. About $4 \mathrm{~kg}$ total soils were collected from the upper 0 to 15 and 15 to $30 \mathrm{~cm}$ using a small spade and shovel. Samples were placed in plastic bags and stored at $4^{\circ} \mathrm{C}[6]$ [15] [18]. 


\subsection{DNA Extraction from Soil}

We used DNA extraction protocol that involves bead beating: a method described previously Griffiths et al. (2000) [19] that uses the MoBio UltraClean soil DNA isolation kit (cat. 12800-100). In the first tests of DNA extraction, the technique described by the supplier was used. However, during the process of extracting some modifications were made. DNA was extracted from 0.25 to $1 \mathrm{~g}$ of soil [15]. Lysis began with the addition of sample to the tubes with beads and homogenizes the sample with stirring. SDS buffer for cell lysis was added. To precipitate humic acids and other PCR inhibitors, the IRS solution (Inhibitor Removal Solution, included in the kit Mo Bio) was added. The tubes were agitated at maximum speed for 10 minutes. In this step, the protocol combines mechanical and chemical lysis. The samples were centrifuged at $10000 \mathrm{rpm}$ for 30 seconds. The supernatant was transferred to a clean tube. At this point the first modification to the DNA extraction protocol was performed, were added $3 \mu \mathrm{l}$ of RNAse A $(3 \mu \mathrm{l} / \mathrm{ml})$ to each sample and incubated at $37^{\circ} \mathrm{C}$ for 1 hour. Finished the incubation, the protein precipitation solution was added. The sample was incubated at $4^{\circ} \mathrm{C}$ for 5 minutes, then centrifuged and the supernatant was transferred to a clean tube. DNA binding salt solution was added. The mixture was charged to spin filter and centrifuged at $10000 \mathrm{rpm}$ for 1 minute. The supernatant was discarded. Wash solution was added within spin filter (ethanol solution) to remove traces of humic acids. Was centrifuged and the supernatant was discarded. A second modification to the extraction technique was performed in this step. Two additional washes with $70 \%$ ethanol were made. And finally, a third modification is performed. The DNA was recovered by adding $50 \mu \mathrm{l}$ of sterile deionized water (preheated to $65^{\circ} \mathrm{C}$ ). DNA samples were stored at $-80^{\circ} \mathrm{C}$ until use. To measure the concentration of DNA was used nanodrop 2000 (Thermoscientific). The DNA obtained was purified by silica membrane columns (adsorption and desorption).

\subsection{PCR Amplification}

PCR assay was designed to amplify a $1.6 \mathrm{~kb}$ region of the $16 \mathrm{~S}$ gene. PCR amplification from $70 \mathrm{ng}$ of extracted soil DNA was conducted with a total volume of $50 \mu \mathrm{l}$ by using $0.5-1 \mu \mathrm{l}(10 \mathrm{mM})$ concentrations of the fD1 primers (5'-CCG AAT TCG TCG ACA ACA GAG TTT GAT CCT GGC TCA G-3') and rD1 (5'CCC GGG ATC CAA GCT TAA GGA GGT GAT CCA GCC-3') and $1.4 \mu 1$ (5 U/ $\mu$ l) of Platinum Taq DNA polymerase (Invitrogen cat. 10966-026) under the following conditions: 3 minutes at $94^{\circ} \mathrm{C}, 30$ cycles of 30 seconds at $94^{\circ} \mathrm{C}, 30$ seconds at $56^{\circ} \mathrm{C}$, and 2 minutes at $72^{\circ} \mathrm{C}$, plus an additional 5 minutes cycle at $72^{\circ} \mathrm{C}$. The original reaction mixture was modified for the PCR assay. Three reaction mixtures were made. In each reaction, the following reagents were added: Reaction mixture 1 . Were added $3 \mu \mathrm{l}$ of $\mathrm{MgCl}_{2}(3 \mathrm{mM}), \mathrm{Reaction}$ mixture 2. 10X BSA $(1 \mu \mathrm{g} / \mu \mathrm{l})$ was added and Reaction mixture 3 . Were added $3 \mu \mathrm{l}$ of $\mathrm{MgCl}_{2}(3 \mathrm{mM})$ and BSA $10 X(1 \mu \mathrm{g} / \mu \mathrm{l})$.

\section{Results}

\subsection{DNA Extraction from Soil}

Following extraction protocol described by the supplier very poor quality ground DNA was observed. The DNA was loaded onto an agarose gel, DNA degradation was observed. The analysis on the nanodrop showed that DNA had a low yield (20 ng/ $\mu \mathrm{l}$ on average) and low purity (260/280: approximately 1.2) (Figure 1). These DNA samples were used in PCR assays, but no amplification was obtained (data not shown). Due to these results, the DNA obtained was purified by silica membrane columns (Figure 2).

With these purified DNA the PCR was repeated and it was possible to obtain an amplification product of 1.6 $\mathrm{Kb}$, however, the amount of amplified was not optimal (Figure 3). Seeing the poor results, modifications to the extraction protocol were made. RNAse A was added to remove any RNA in the sample and before eluting the DNA were further washed with $70 \%$ ethanol. The DNA was eluted with water instead of the suggested buffer. The analysis in nanodrop showed better concentration (40 ng/ $\mu \mathrm{l}$ on average) and a purity of 1.8 (260/280). The samples were loaded on an agarose gel and no traces of RNA or DNA degradation were observed (Figure 4).

\subsection{PCR Amplification}

PCR amplification. DNA samples of soil obtained in the extraction protocol (modified) were used in PCR assays occupying the original reaction mixture. Expected amplification was obtained, however, the amount of ampli- 


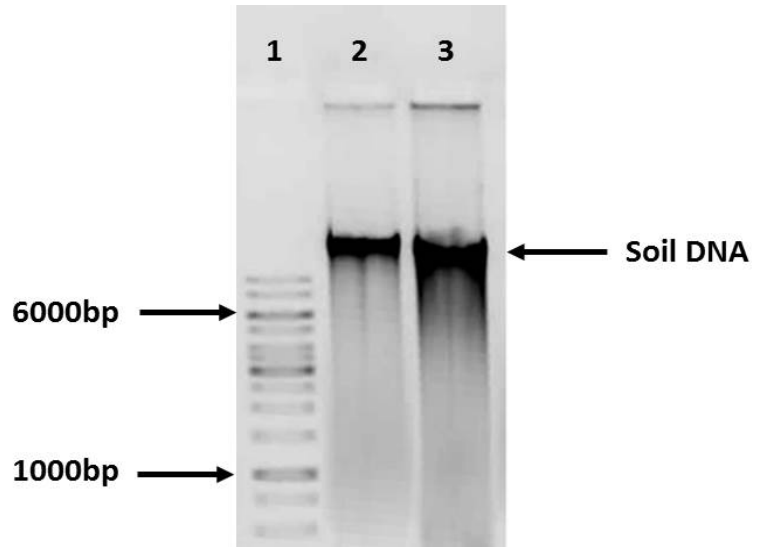

Figure 1. Agarose gel electrophoresis $(0.8 \%)$ of Soil DNA. Lane 1: Molecular weight $1 \mathrm{~Kb}$ (Fermentas cat. SM0314). Lanes 2 - 3: Soil DNA samples (30ng). DNA degradation was observed.

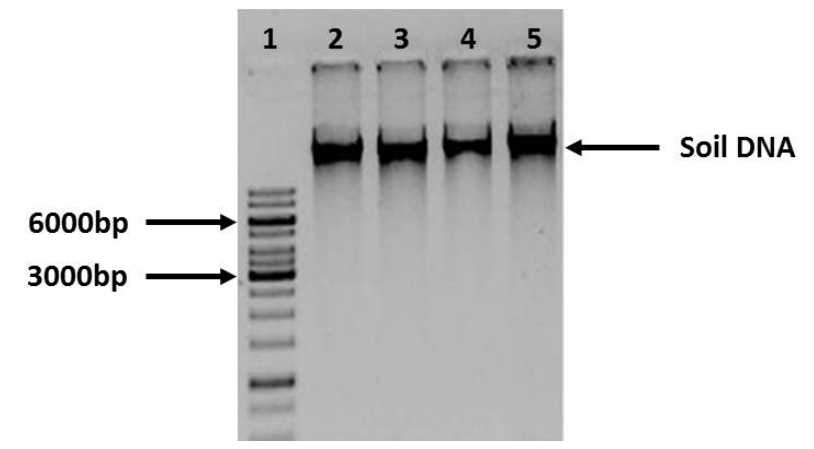

Figure 2. Agarose gel electrophoresis $(0.8 \%)$ of Soil DNA purified by column. Lane 1: Molecular weight $1 \mathrm{~Kb}$ (Fermentas cat. SM0314). Lanes 2 - 5: Soil DNA samples (30 ng). No degradation was observed in the samples..

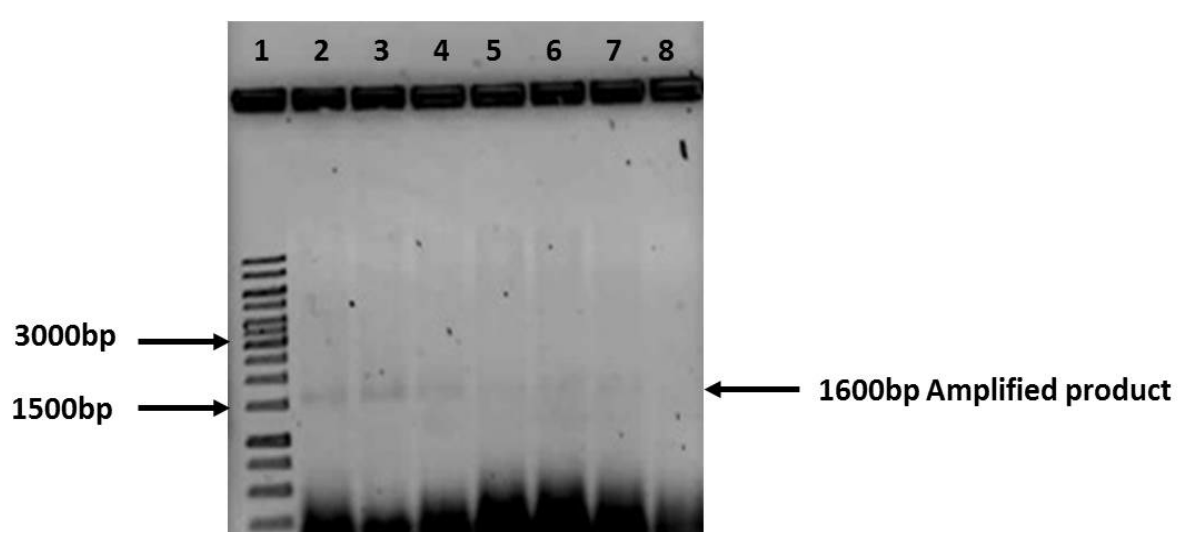

Figure 3. Agarose gel electrophoresis ( $0.8 \%)$ of PCR products (Soil DNA purified by colum). Lane 1: Molecular weight $1 \mathrm{~Kb}$ (Fermentas cat. SM0314). Lanes 2 - 8: $1600 \mathrm{bp}$ amplified product using fD1 and rD1 primers (16S rDNA gene). Amplified observed, however, the intensity is low.

fied was very weak. The PCR protocol was also modified. To the reaction mixture were added contaminants inhibitors (BSA and $\mathrm{MgCl}_{2}$ ) at different final concentrations each. In the first reaction mixture will be added only 


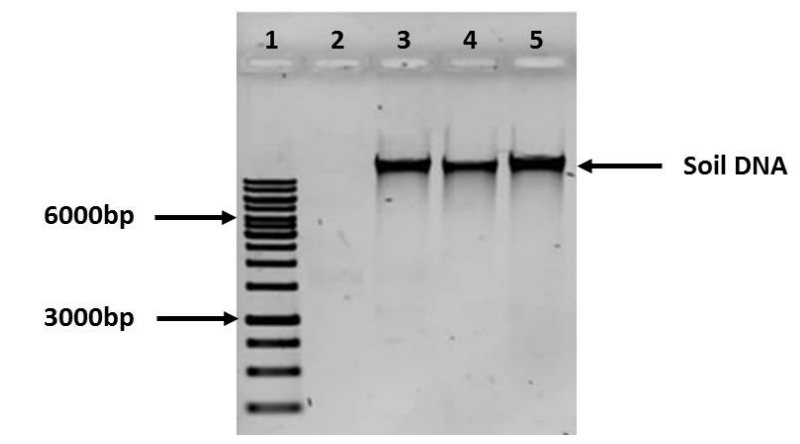

Figure 4. Agarose gel electrophoresis $(0.8 \%)$ of Soil DNA (Modified Protocol). Lane 1: Molecular weight $1 \mathrm{~Kb}$ (Fermentas cat. SM0314). Lane 2: Empty. Lanes 3 - 5: Soil DNA samples $(30 \mathrm{ng})$. DNA is observed without degradation or presence of RNA.

$\mathrm{MgCl}_{2}$. The second reaction mixture was added BSA, while the third reaction mixture was a combination of both inhibitors (BSA/ $\mathrm{MgCl}_{2}$ ). In all three PCR assays were obtained the expected amplified. However, when loaded on an agarose gel, the most intense amplification was observed in the reaction mixture number $1\left(\mathrm{MgCl}_{2}\right.$ only) (Figure 5).

\section{Discussion}

The biosphere is dominated by microorganisms, yet most microbes in nature have not been studied. Traditional methods for culturing microorganisms limit analysis to those that grow under laboratory conditions [20]. Up to now, most of the microbial diversity studies conducted in complex ecosystems, such as soil, has been biased essentially by the unculturability of many microorganisms and the lack of sensitivity of traditional microbiological methods [21]. The number of microorganisms typically cultured from soil represents a little part of the total microbial community [22]. One gram of soil has been reported to contain up to 10 billion microorganisms and thousands of different species. Currently, less than $1 \%$ of this diversity is considered to be cultivable by traditional techniques, a problem that can be circumvented by metagenomic approaches [15] In fact, most of the species in many environments have never been described, and this situation will not change until new culture technologies are developed. Additionally, many techniques currently used to explore the diversity and potential of microbial communities are biased because of the limitations of cultivation methods [8] [10]. There are problems associated with studying bacterial and fungal diversity in soil. These arise not only from methodological limitations, but also from a lack of taxonomic knowledge. It is difficult to study the diversity of a group of microorganisms when it is not understood how to categorize or identify the species present [23]. For more than a decade, metagenome research has demonstrated that it is a powerful tool for the discovery of novel biocatalysts and other valuable biomolecules by using either function or sequence-based screening technologies, addition to its impact on bacterial biodiversity. Sequence-based approaches allow the identification of candidate genes [24]. In the last years were studies initiated to investigate the metagenome [13]. Metagenomics is a new and rapidly developing field that tries to analyze the complex genomes of microbial niches. Although the term metagenome has been introduced only recently to describe the genomes of cultivated and noncultivated microbes present within a soil microbial community, earlier studies used a similar approach [10]. Our soil samples were taken from sugarcane rhizosphere soil. Soil bacteria and, in particular, rhizosphere bacteria play an important role in many processes, such as decomposition, mineralization, biological nitrogen fixation, and denitrification [25]. This because the soil is a virtual limitless pool of genetic information contained in bacteria and eukaryotic organism as reported by Trevors et al. (1998) [26]. As describe Pisa et al. (2011) [25], the investigation of bacterial diversity is an important step to assess soil conditions due to its importance in nutrient cycling, and consequently in crop productivity. Initially, metagenomics was used mainly to recover novel biomolecules from environmental microbial assemblages. However, the development of next-generation sequencing techniques and other affordable methods allowing large-scale analysis of microbial communities resulted in novel applications, such as comparative community metagenomics, metatranscriptomics, and metaproteomics [4]. Since only a mi- 


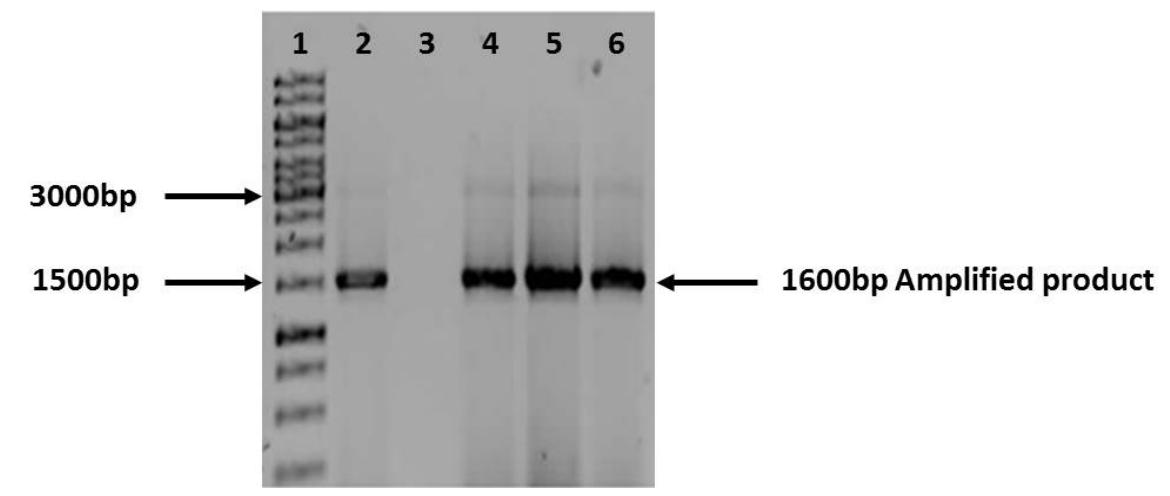

Figure 5. Agarose gel electrophoresis $(0.8 \%)$ of PCR products (Modified Protocol). Lane 1: Molecular weight $1 \mathrm{~Kb}$ (Fermentas cat. SM0314). Lane 2: Amplified product (1600 bp) (Without BSA/ $\mathrm{MgCl}_{2}$ ). Lane 3: Negative control. Lane 4: Amplified product (1600 bp) (BSA). Lane 5: Amplified product (1600 bp) $\left(\mathrm{MgCl}_{2}\right)$. Lane 6: Amplified product (1600 bp) (BSA/ $\mathrm{MgCl}_{2}$ ). $1600 \mathrm{bp}$ amplified product using fD1 and $\mathrm{rD1}$ primers (16S rDNA gene) in all lanes.

nor proportion of soil microorganisms are culturable on standard media, analysis of directly extracted DNA has the potential to detect specific genes of otherwise cryptic microorganisms or monitor changes in the genotypic diversity of soil microbial communities [16]. The extraction of DNA from soil was complicated, despite using commercial kits for extraction we had difficulty obtaining quality DNA. Our first DNA extractions showed remnants of RNA (data not shown) as well as the co-purification of humic acids (these acids are not observed, in addition to an agarose gel migrate to the same speed as the extracted DNA), this is consistent with that reported by Rajendhran and Gunasekaran (2008), where describe that the co-purification of contaminants such as humic compounds is a major problem associated with various soil metagenomic projects. These contaminants are not completely removed during classical DNA extraction protocols, such as detergent, phenol-chloroform and protease treatments. The mechanism of purification of these kits is based on the adsorption and desorption of the nucleic acids in presence of chaotropic salts. Under native conditions, the nucleic acids are covered by a layer hydrating water molecules that maintain the solubility of DNA in aqueous solutions. With the addition of chaotropic ions to nucleic acids, the ordered structure of water molecules moisturizer layer is destroyed, so that the chaotropic salts create a hydrophobic environment around the DNA. Under these hydrophobic conditions, nucleic acids will bind tightly to the silica membrane column, while proteins, metabolites or other contaminants do not bind and therefore, are removed from the sample during the washing steps. Subsequently, the nucleic acids are eluted from the silica membrane with elution buffers with a low salt concentration (slightly alkaline) or simply water, and hydrating for retrieving the nucleic acid layer, thereby freeing the membrane. We use the modification of the technique described in the extraction protocols. Commercial DNA extraction kits are now commonly used in the assessment of taxonomic and functional diversity, community composition, and population abundance. Studies comparing various kits or comparing commercial kits to other methods have shown that DNA yield and purity vary depending on methodology and soil type. While these comparative studies are valuable, it is still unclear to what extent these protocols yield genomic DNA representative of the microbial community found within soil (Feinstein et al. 2009). Before eluting the DNA, several washings with ethanol at $70 \%$ were made to remove traces of humic acids and other contaminants. The DNA was obtained with protocol modifications showed a satisfactory result increasing their yield and purity $(20 \mathrm{ng} / \mu \mathrm{l}$ to $40 \mathrm{ng} / \mu \mathrm{l})$. This is consistent with that described by several authors to extract DNA from soil [7] [16] [21]. RNAse adding contributed to DNA purification by removing the remains of RNA in samples (Figure 4). On the other hand, humic substances are a major reservoir of organic carbon in soils, sediments, and water, and their fate is relevant to carbon cycling in these environments. In soil, humic acid formation involves the enzymatic and chemical condensation of natural polyphenols, quinones, and amino compounds. In the extraction of total DNA, always results in coextraction of other soil components, mainly humic acids, which negatively interfere with DNA transforming and detecting processes. It has been reported that those substances inhibit restriction endonucleases, and Taq polymerase, the enzyme of the polymerase chain reaction (PCR), and decrease efficiencies in DNA-DNA hybridizations [16]. PCR analysis provides a sensitive and specific means to detect and monitor microorganisms in complex environmental samples and the PCR can act as a quality control to determine the purity and quality of soil DNA. 
Successful detection and characterization of microbial DNA in the environment require efficient extraction of the DNA from environmental samples and adequate purification from the co-extracted contaminants that inhibit PCR [27] [28]. DNA contamination with humic acids has resulted in PCR inhibition and microbial diversity bias. Solutions were found in the dilution of the template DNA, which improved both PCR performance and recovered diversity in some soils, or, in contrast, by increasing the amount of template DNA, which was effective in other soils. However, it seems that further purification of template DNA is preferred to DNA dilution because a loss of diversity is more likely with dilution [18]. Humic acids are inhibitors of Taq polymerase in the PCR which may degrade or capture DNA or can block the active site of the polymerase. These acids are co-extracted with the soil DNA, however, the $\mathrm{MgCl}_{2}$ and BSA decreased inhibition by contaminants such as humic acids and make more efficient the enzyme and trapping certain inhibitory compounds. Using $\mathrm{MgCl}_{2}$ and $\mathrm{BSA}$ showed good results in the amplification of the PCR product. $\mathrm{MgCl}_{2}$ and BSA are used in PCR assays for their ability to remove inhibitors from soil metagenomic DNA. The $\mathrm{MgCl}_{2}$ is better inhibitor of humic acids than the BSA (Figure 5). With the addition of $\mathrm{MgCl}_{2}$ to the reaction mixture, the amplified intensity increased. $\mathrm{MgCl}_{2}$ is a necessary cofactor for the enzymatic activity of DNA polymerase. This is consistent with those reported by several authors who have used these inhibitors of contaminants [3] [5] [7] [10] [16]-[18] [27]-[30]. In general, the production of sugarcane is of great importance for the Papaloapan Basin, this because in this region, is located a sugar mill, which represents major financial support for the community. The modifications to the techniques of DNA extraction and PCR protocol showed good results on the quality and quantity of DNA and amplification of the PCR product, is important to note that all modifications to the techniques can be performed with basic laboratory equipment. Although protocols for extraction of DNA from soils have progressed, the quality and quantity of DNA are still low compared with culturable microorganisms. DNA purification is a critical step in soil DNA extraction, once the problems with lysis are overcome. Over time, bead beating has been recommended as the most effective technique in soil aggregate and cell disruption and is also used in commercial kits [18]. However, the modification of techniques used by several authors has allowed the extraction of better quality DNA for use in PCR assays, identification of microorganisms, digestions, ligations, and library construction.

\section{Conclusion}

Currently, there are no studies about soil metagenomics of sugarcane cultivation in the region of the Papaloapan Basin in Mexico. It is very important to develop metagenomic studies on these soils that are rich in agriculture and the diversity of microorganisms. In this work, it is the first time the extraction of DNA from soil in this region is performed, and the PCR assays to amplification $16 \mathrm{~S}$ rDNA gene as quality control soil DNA. These results open the way to continue performing metagenomics studies in this region and then identify bacteria with cellulase or amylase activity that are of interest to our research group.

\section{Acknowledgements}

This work was supported by Consejo Nacional de Ciencia y Tecnología (CONACyT) 154683 and Programa de Mejoramiento para el Profesorado (PROMEP) 2009-02 103.5/11/6149 projects. Gutierrez-Lucas LR, CortésLópez NG, Montor-Antonio JJ thanks CONACyT by the grants 171724, 20254 and 28094, respectively. The authors declare that they have no conflict of interest.

\section{References}

[1] Montor-Antonio, J.J., Olvera-Carranza, C., Reyes-Duarte, D., Sachman-Ruíz, B., Ramírez-Coutiño, L.P. and Del Moral, S. (2014) Biochemical Characterization of AmiJ33 an Amylase from Bacillus Amyloliquefaciens Isolated of Sugarcane Soils at the Papaloapan Región. Nova Scientia, 6, 39-59.

[2] Rodríguez-Vallejo, J. (1977) Recursos Naturales de la Cuenca del Papaloapan. Tomo II. El Desarrollo Agrícola, México.

[3] Rajendhran, J. and Gunasekaran, P. (2008) Strategies for Accessing Soil Metagenome for Desired Applications. Biotechnology Advances, 26, 576-590. http://dx.doi.org/10.1016/j.biotechadv.2008.08.002

[4] Simon, C. and Daniel, R. (2011) Metagenomic Analyses: Past and Future Trends. Applied and Environmental Microbiology, 77, 1153-1161. http://dx.doi.org/10.1128/AEM.02345-10

[5] Feinstein, M.L., Sul, W.J. and Blackwood, C.B. (2009) Assessment of Bias Associated with Incomplete Extraction of Microbial DNA from Soil. Applied and Environmental Microbiology, 75, 5428-5433.

http://dx.doi.org/10.1128/AEM.00120-09 
[6] Torsvik, V., Goksoyr, J. and Daae, F. (1990) High Diversity in DNA of Soil Bacteria. Applied and Environmental Microbiology, 56, 782-787.

[7] Miller, D.N., Bryant, J.E., Madsen, E.L. and Ghiorse, W.C. (1999) Evaluation and Optimization of DNA Extraction and Purification Procedures for Soil and Sediment Samples. Applied and Environmental Microbiology, 65, 4715-4724.

[8] Diaz-Torres, M.L., McNab, R., Spratt, D.A., Villedieu, A., Hunt, N., Wilson, M. and Mullany, P. (2003) Novel Tetracycline Resistance Determinant from the Oral Metagenome. Antimicrobial Agents and Chemotherapy, 47, 1430-1432. http://dx.doi.org/10.1128/AAC.47.4.1430-1432.2003

[9] McGarvey, K.M., Queitsch, K. and Fields, S. (2012) Wide Variation in Antibiotic Resistance Proteins Identified by Functional Metagenomic Screening of a Soil DNA Library. Applied and Environmental Microbiology, 78, 1708-1714. http://dx.doi.org/10.1128/AEM.06759-11

[10] Schmeisser, C., Stöckigt, C., Raasch, C., Wingender, J., Timmis, K.N., Wenderoth, D.F., Flemming, H.C., Liesegang, H., Schmitz, R.A., Jaeger, K.E. and Streit, W.R. (2003) Metagenome Survey of Biofilms in Drinking-Water Networks. Applied and Environmental Microbiology, 69, 7298-7309. http://dx.doi.org/10.1128/AEM.69.12.7298-7309.2003

[11] Jones, M.D., Singleton, D.R., Sun, W. and Aitken, M.D. (2011) Multiple DNA Extractions Coupled with Stable-Isotope Probing of Anthracene-Degrading Bacteria in Contaminated Soil. Applied and Environmental Microbiology, 77, 29842991. http://dx.doi.org/10.1128/AEM.01942-10

[12] Elend, C., Schmeisser, C., Leggewie, C., Babiak, P., Carballeira, J.D., Steele, H.L., Reymond, J.L., Jaeger, K.E. and Streit, W.R. (2006) Isolation and Biochemical Characterization of Two Novel Metagenome-Derived Esterases. Applied and Environmental Microbiology, 72, 3637-3645. http://dx.doi.org/10.1128/AEM.72.5.3637-3645.2006

[13] Voget, S., Leggewie, C., Uesbeck, A., Raasch, C., Jaeger, K.E. and Streit, W.R. (2003) Prospecting for Novel Biocatalysts in a Soil Metagenome. Applied and Environmental Microbiology, 69, 6235-6242. http://dx.doi.org/10.1128/AEM.69.10.6235-6242.2003

[14] Schmitz, J.E., Daniel, A., Collin, M., Schuch, R. and Fischetti, V.A. (2008) Rapid DNA Library Construction for Functional Genomic and Metagenomic Screening. Applied and Environmental Microbiology, 74, 1649-1652. http://dx.doi.org/10.1128/AEM.01864-07

[15] Delmont, T.O., Robe, P., Cecillon, S., Clark, I.M., Constancias, F., Simonet, P., Hirsch, P.R. and Vogel, T.M. (2011) Accessing the Soil Metagenome for Studies of Microbial Diversity. Applied and Environmental Microbiology, 77, 1315-1324. http://dx.doi.org/10.1128/AEM.01526-10

[16] Tebbe, C. and Vahjen, W. (1993) Interference of Humic Acids and DNA Extracted Directly from Soil in Detection and Transformation of Recombinant DNA from Bacteria and a Yeast. Applied and Environmental Microbiology, 59, 26572665.

[17] Hurt, R.A., Qiu, X., Wu, L., Roh, Y., Palumbo, A.V., Tiedje, J.M. and Zhou, J. (2001) Simultaneous Recovery of RNA and DNA from Soils and Sediments. Applied and Environmental Microbiology, 67, 4495-4503. http://dx.doi.org/10.1128/AEM.67.10.4495-4503.2001

[18] Sagova-Mareckova, M., Cermak, L., Novotna, J., Plhackova, K., Forstova, J. and Kopecky, J. (2008) Innovative Methods for Soil DNA Purification Tested in Soils with Widely Differing Characteristics. Applied and Environmental Microbiology, 74, 2902-2907. http://dx.doi.org/10.1128/AEM.02161-07

[19] Griffiths, R.I., Whitely, A.S., O’Donnell, A.G. and Bailey, M.J. (2000) Rapid Method for Coextraction of DNA and RNA from Natural Environments for Analysis of Ribosomal DNA- and rRNA-Based Microbial Community Composition. Applied and Environmental Microbiology, 66, 5488-5491. http://dx.doi.org/10.1128/AEM.66.12.5488-5491.2000

[20] Rondon, M.R., August, P.R., Bettermann, A.D., Brady, S.F., Grossman, T.H., Liles, M.R., Loiacono, K.A., Lynch, B., MacNeil, I.A., Minor, C., Tiong, C.L., Gilman, M., Osburne, M.S., Clardy, J., Handelsman, J. and Goodman, R.M. (2000) Cloning the Soil Metagenome: A Strategy for Accessing the Genetic and Functional Diversity of Uncultured Microorganisms. Applied and Environmental Microbiology, 66, 2541-2547. http://dx.doi.org/10.1128/AEM.66.6.2541-2547.2000

[21] Martin-Laurent, F., Philippot, L., Hallet, S., Chaussod, R., Germon, J.C., Soulas, G. and Catroux, G. (2001) DNA Extraction from Soils: Old Bias for New Microbial Diversity Analysis Methods. Applied and Environmental Microbiology, 67, 2354-2359. http://dx.doi.org/10.1128/AEM.67.5.2354-2359.2001

[22] Gillespie, D.E., Brady, S.F., Bettermann, A.D., Cianciotto, N.P., Liles, M.R., Rondon, M.R., Clardy, J., Goodman, R. M. and Handelsman, J. (2002) Isolation of Antibiotics Turbomycin A and B from a Metagenomic Library of Soil Microbial DNA. Applied and Environmental Microbiology, 68, 4301-4306. http://dx.doi.org/10.1128/AEM.68.9.4301-4306.2002

[23] Kirk, J.L., Beaudette, L.A., Hart, M., Moutoglis, P., Klironomos, J.N., Lee, H. and Trevors, J.T. (2004) Methods of Studying Soil Microbial Diversity. Journal of Microbiological Methods, 58, 169-188.

http://dx.doi.org/10.1016/j.mimet.2004.04.006 
[24] Rabausch, U., Juergensen, J., Ilmberger, N., Böhnke, S., Fischer, S., Schubach, B., Schulte, M. and Streit, W.R. (2013) Functional Screening of Metagenome and Genome Libraries for Detection of Novel Flavonoid-Modifying Enzymes. Applied and Environmental Microbiology, 79, 4551-4563. http://dx.doi.org/10.1128/AEM.01077-13

[25] Pisa, G., Magnani, G.S., Weber, H., Souza, E.M., Faoro, H., Monteiro, R.A., Daros, E., Baura, V., Bespalhok, J.P., Pedrosa, F.O. and Cruz, L.M. (2011) Diversity of 16S rRNA Genes from Bacteria of Sugarcane Rhizosphere Soil. Brazilian Journal of Medical and Biological Research, 44, 1215-1221. http://dx.doi.org/10.1590/S0100-879X2011007500148

[26] Trevors, J.T. (1998) Bacterial Biodiversity in Soil with an Emphasis on Chemically-Contaminated Soils. Water, Air, \& Soil Pollution, 101, 45-67. http://dx.doi.org/10.1023/A:1004953404594

[27] Kuske, C.R., Banton, K.L., Adorada, D.L., Stark, P.C., Hill, K.K. and Jackson, P.J. (1998) Small-Scale DNA Sample Preparation Method for Field PCR Detection of Microbial Cells and Spores in Soil. Applied and Environmental Microbiology, 64, 2463-2472.

[28] Tsai, Y. and Olson, B. (1992) Rapid Method for Separation of Bacterial DNA from Humic Substances in Sediments for Polymerase Chain Reaction. Applied and Environmental Microbiology, 58, 2292-2295.

[29] Chandna, P., Mallik, S. and Chander, R. (2013) Assessment of Bacterial Diversity in Agricultural By-Product Compost by Sequencing of Cultivated Isolates and Amplified rDNA Restriction Analysis. Applied Microbiology Biotechnology, 97, 6991-7003. http://dx.doi.org/10.1007/s00253-012-4434-0

[30] Steffan, R.J., GoksØyr, J., Bej, A. and Atlas, R.M. (1988) Recovery of DNA from Soils and Sediments. Applied and Environmental Microbiology, 54, 2908-2915. 